Send your letters to the editor, British Dental Journal, 64 Wimpole Street, London W1G 8YS or by email to bdj@bda.org

Priority will be given to letters less than 500 words long. Letters should be typed. Authors must sign the letter, which may be edited for reasons of space

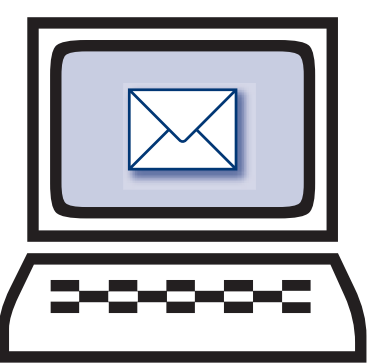

Dental treatment and CJD risk

Sir, we wish to inform readers of a forthcoming Department of Health funded study to investigate the possibility of retrieving the dental case records of patients affected by CJD (sporadic and variant) and to note the types of treatment undertaken. We stress that we have no reason to suspect that dental treatment is linked in any way to the development of CJD. This work is part of a process of eliminating another potential risk factor to provide a clearer understanding of how CJD develops. This project forms part of the portfolio of work being undertaken by the National CJD Surveillance Unit (NCJDSU) investigating potential risk factors for the development of CJD.

The project is a small-scale study to identify how difficult or easy it is to access the dental records from CJD patients and a control group of unaffected people, who have given consent. If the study is successful then there is a possibility that we will examine many more case records. At present we plan to look at dental records from 16 patients who have had CJD across Scotland, England, Wales and Northern Ireland and 32 unaffected people as controls.

The study has full ethical approval from Lothian Multi-centre Research Ethics Committee as part of the NCJDSU's ongoing case control study examining risk factors for variant and sporadic CJD.

We would welcome any comments that readers may have on this study. Please feel free to contact us at the address below.

A. Smith

A. P. Matthewson

Infection Research Group, Level 9, Glasgow Dental Hospital \&t School, 378 Sauchiehall

Street, Glasgow G2 3JZ

a.smith@dental.gla.ac.uk

01412119747

doi: 10.1038/sj.bdj.4812914

\section{Manpower problems}

Sir, Professor Sheiham's editorial (BDJ

2005; 199: 187) gives an interesting perspective on the feminisation of dentistry and the current dental manpower problems. However he does not seem to recognise a major cause of these problems and his solutions will result in negligible improvements in patient health care.

There are many causes, but I believe the most important factor in our failure to deliver dental care to the patients of the UK is the obscene manpower wastage. Females form $60 \%$ of current dental graduates and currently account for 34\% of dentists [this will rise to over $50 \%$ in a few years]. The respected Government funded Seward Report into working patterns of female dentists revealed that not only are females under represented in working hours [more than half work only two days a week], they are also under represented in practice ownership, involvement in postgraduate training and policy-making bodies. This has serious ramifications for high street dentistry and as more males retire there will be nobody to take practices over.

Current undergraduate selection processes are mainly based on 'A' level grades but there are many other important selection criteria that are seemingly ignored. If 90\% of dental graduates were male then the manpower problem would be well on the way to being solved and importantly at no extra cost. Dentists are amongst the most expensive graduates to train, [I believe it is in the region of $£ 250 \mathrm{~K}$ each] and yet simply training extra female dentists at this huge cost will, in my view, do little to solve the problem. When I have simply asked these questions at BDA conferences, angry females shout me down and our BDA representatives have looked embarrassed and quickly changed the subject.

When equal opportunities clash head on with health care needs it creates an impossible problem. Of course there are very good reasons for female working patterns but it must be stated categorically that this developing trend accounts for a significant part of the current shortage of dentists. I do not begin to know how to overcome these barriers but we cannot hide any more because quite rightly, the public will not stand for it. The time has come when we need strong leadership and be prepared to 'walk the talk' instead of timid climbdowns.

I feel I must express these arguable politically incorrect views but for years I have been predicting these problems and was never taken seriously by shortterm political dictum. The BDA is complacently presiding over what is fast becoming an absolute scandal as is illustrated by national headlines when a new NHS practice opens. Patients are being denied basic health care and we are failing to face up to this worsening scenario; it cannot last. The current management strategy is creating an inevitable and severe professional crisis.

\section{Thomas}

Wolverhampton

doi: 10.1038/sj.bdj.4812915

\section{Cinderella of the NHS?}

Sir, while I totally agree with Professor Aubrey Sheiham in his recent editorial (BDJ 2005; 199: 187) that HMG's new NHS short-term contracts and great uncertainty will cause worse NHS dental services, not better, I believe he has stated this conclusion correctly, but for all the wrong reasons!

His opening sentence 'The dramatic improvements in dental health...' simply adds credence to the saying: 'Lies, damn lies and statistics!'

UK dental health is now so bad that the second commonest reason for the UK population to contact NHS Direct for all medical conditions, is toothache. ${ }^{1}$

There are lengthy queues simply to register with NHS dentists to get even basic, urgent needs attended to, never mind continuing quality care and prevention. $^{2}$

The 'British mouth' of high disease and bad breath, as it is referred to derogatorily world-wide, is increasing rather than decreasing - the evidence is all around us and any 'scientist' would have to be 'double-blind' to not see this!

In the future, history will have to remind itself these were not Victorian times, but twenty-first century NHS dental services failing to live up to government 
spin, while being poorly planned and even more poorly resourced. Dental teams' goodwill and hard work simply cannot compensate for such long-standing, continuing incompetence from central government planners!

It was the Government's 'in-house' scientific advice in the late 1980s and a wish to cut costs that closed two UK dental schools and cut NHS Dental funding in 1992 dramatically. Those strategies were clearly wrong and not in the public interest. ${ }^{3}$

Today we have to import so many 'extra' non-UK dentists that they form the majority by far of new GDC registrants annually and we STILL have a big dental workforce shortage. Professor Aubrey Sheiham's editorial, by deflecting most of our attention onto the increasing proportion of female UK dental graduates and supposedly lower dental treatment needs, is at best misguided and at worst insulting to our female colleagues and the general intelligence of this esteemed journal's readership.

Without doubt if this Government also continues with its plans to perpetuate and further reinforce these serious errors of the last 15 years by massively under-resourcing NHS dentistry, on previous invalid assumptions of fewer future dental needs, rather than the obvious growing mountain of unmet dental needs, then this promised new NHS dental system is still heading for its predictable, catastrophic failure. ${ }^{4}$

No wonder privately provided, patientcentred dental care and prevention is increasingly attractive to both dental professionals and their patients than the NHS alternative! ${ }^{5}$

UK dentistry deserves a better thought out and co-coordinated national strategy for overall dental care delivery, than that still based on the failed, past dogmas that continue to treat dentistry as the 'discriminated' Cinderella of NHS services. ${ }^{6}$

Until that paradigm shift in central

Government thinking occurs, this new draft NHS dental contract is still working against the public interest, by design or default.

\section{A. Kilcoyne}

\section{By email}

1. House of Commons official report, 28 June 2005: Co $1521 \mathrm{~W}$

2. D. Parkinson. Want to see the NHS dentist? Join the mile-long queue. Daily Mail. 21 Mar 2005.

3. What happened to NHS dentistry? BBCNews Magazine, 19 Feb 2004.

T. Kilcoyne. Dental strategy. Br Dent J 2001; 190: 58

5. Commission for Healthcare Auditand Inspection State of Healthcare Report. p 8, 21, 53, 59. 18 July 2005.

6. Department of Health. Reforming NHS dentistry Ensuring effective management of risks. Part 1. National Audit Office. pp 13-14. 25 Nov 2004.

\section{Contempt for the Welsh}

Sir, Dr Nigel L. Carter seems to think that it is unnecessary to use the Welsh language because those who speak it are 'in relatively small numbers'. The word 'relatively' I presume means in comparison with English. There is a hint of English arrogance and contempt for the Welsh here, and a suggestion that small minorities don't matter and can be safely ignored. He also writes of 'national campaigns' where 'national' appears to mean 'English'.

During the past century there has been a growing awareness that Wales is a nation and that Welsh is its national language. Many English people regard this as dangerous nationalism while they are blind to the more extreme nationalism expressed in singing at the last night of the Proms: 'Wider still and wider let thy bounds be set. God who made thee mighty make thee mightier yet'. While singing these words most English people wave the Cross of St George, not the Union Jack, as they do on other flag waving occasions. This shows that they regard England, not Britain or the UK, as their nation.

In 1852 Mathew Arnold said that: 'It must always be the desire of a government to render its dominions, as far as possible homogenous ... Sooner or later, the difference of language between Wales and England will probably be effaced ... an event which is socially and politically desirable.'

There are many who still regard it as desirable, and do not realise that contempt for a language is at the same time contempt for the people whose language it is. The insistence that campaign literature for use in Wales must be in Welsh as well as English is largely a Welsh response to such English contempt. The 'health of the Welsh people' to which Dr Carter refers in his last sentence involves something more than regarding them as bodies with teeth in their mouths. And one part of that something more is the language which they have inherited and which many thousands of us still speak in spite of the efforts to force us to use only the English language.

\section{F. M. Jones}

\section{Cardiff}

doi: 10.1038/sj.bdj.4812917

\section{Ruth Ellis's dentist}

Sir, I am the ghost writer of Ruth Ellis My Sister's Secret Life by Muriel Jakubait with Monica Weller. Fifty years ago Ruth Ellis was the last woman to be hanged in Britain. She was convicted for shooting her lover David Blakely. It has taken considerable effort stripping away the fact from the fiction in Ruth's story.

Although our book was published in July 2005 I am carrying out further research about George Johnston Ellis, the dentist who Ruth married in 1950. I am hoping that readers of the $B D J$ may have some useful information and recollections about him.

If this helps, George was born in 1909, graduated from Manchester School of Dentistry in 1933, had a practice on Sanderstead Hill in Surrey until 1950, became a school dentist in Warrington until 1955 and apparently committed suicide in 1958 in a Jersey hotel. During and just after the Second World War he was a regular customer at the White Hart Hotel, Brasted in Kent which was known as the unofficial HQ of the Battle of Britain pilots.

Please write to me in confidence c/o our publisher:

For the personal attention of Monica

Weller, c/o Constable and Robinson, 3

The Lanchesters, 162 Fulham Palace

Road, London, W6 9ER

or email: monicaweller13@hotmail.com. Thank you.

M. Weller

By email

doi: 10.1038/sj.bdj.4812918

\section{Legality and ethics}

Sir, I have just been reading through the GDC's Standards for dental professionals. The first standard states:

'Put patients' interests before your own or those of any colleague, organisation or business.'

Many dentists would believe that a course of night guard bleaching is more in the interest of a patient concerned about the colour of their teeth, than cutting precious tooth tissue to provide crowns or veneers. Unfortunately this choice could still lead to a six month prison sentence for any dentist that puts the interest of a patient over that of the Department of Trade and Industry. Surely it is time that this anomaly, demonstrating the difference between legality and ethics, was rectified?

\section{P. Thornley}

Sutton Coldfield

doi: $10.1038 /$ sj.bdj.4812919

\section{Five-step definition}

Sir, I was saddened to read in J. Ahearne's letter (BDJ 2005; 199: 315) that he believes that a 'clear definition of what constitutes evidence based dentistry' is needed.

I believe that a definition already exists. ${ }^{1}$ It is 'the conscientious, explicit 
and judicious use of current best evidence in making decisions about individual patients ... integrating individual clinical expertise with the best available external clinical evidence from systematic research'. The traditional approach involves a fivestep model. ${ }^{2}$ There is, of course, practical difficulty in applying the model, particularly since patients and presentations are rarely identical. Nevertheless, I will try briefly to work through the process, given Dr Ahearne's clinical scenario of a pregnant patient showing signs of periodontitis attending for a dental examination.

1. Asking an answerable clinical question In this scenario, the question might be: 'can active periodontal disease during pregnancy cause pre-term delivery or an underweight baby?'

\section{Searching for the evidence}

This requires good searching skills, tailored to the focus of the question developed. It also requires interrogation of appropriate sources of evidence, eg Medline database, Cochrane library. A systematic review or a 'best-evidence synthesis', ${ }^{3}$ might be the optimal type of publication to look for. If no reasonably current systematic review is available, you may have to decide to look at the results of some observational studies, (such as the cohort study of Moore et $a l .{ }^{4}$ or the casecontrol study of Radnai et al. ${ }^{5}$ ).

Randomised controlled trials would not be possible, for ethical reasons. Your choice of which papers to look at would probably be dictated by the titles, abstracts, easy availability of the full-text article, and time you had available.

\section{Critically appraising the evidence for} its validity and relevance

This requires a systematic approach. Use of a relevant 'checklist' can assist greatly. Bias can creep in to all aspects of evidence, including that existing in the reader's subconscious! In the two papers by Moore et $a l .{ }^{4}$ and Radnai et al., ${ }^{5}$ the critical appraisal process led in one forum $^{6}$ to the conclusion that the results of the latter may be misleading, whereas the former appeared to be a wellconstructed study of 'higher' methodological weight, appropriate to the question. It would be worth looking at other evidence if you had time, since there may be some better quality evidence which supports the 'flawed' study, and it is hard to ignore a lot of evidence favouring one particular view, even if it is not of optimum quality. (No smoke without fire!)
4. Making a decision, by integrating the evidence with your clinical expertise and the patient's values

You cannot assume that a pregnant patient wishes the best outcome for her baby. I once had a pregnant lady tell me that she intended to continue to smoke during her pregnancy because she did not want a large baby! Based on the process at 1-3 above, it might be appropriate to advise that there has been some work which suggests that periodontitis during pregnancy can have an adverse effect, but it is not clear whether this is true, because studies have shown conflicting results. Explaining things in this way would form part of the information and consent process for the patient, who should be told about her periodontal condition anyway, and offered relevant treatment.

\section{Evaluating your performance}

Reflecting on the process undergone at steps 1-4 is one method. Try describing and analysing what happened during the process, your thoughts and feelings, what was good and bad about the experience, what else you could have done and what you will now do, either to improve the way you handle a similar situation in future, or as a result of your experience.

It's not easy, but it is worthwhile and you will be able to demonstrate a considered process for your practice. Good luck.

\section{H. Beckett}

By email

1. Sackett $D$ L et al. Evidence based medicine: what it is and what it isn't. Br Med J 1996: 312: 71-72.

2. Badenoch D, Heneghan C. Evidence-based medicine toolkit. UK: BMJ Books, 2002.

3. Slavin R. Best evidence synthesis: An intelligent alternative to meta-analysis. J Clin Epidemio/ 1995; 48: 9-18

4. Moore S et al. A prospective study to investigate the relationship between periodontal disease and adverse pregnancy outcome. BrDent J 2004; 197: 251-258.

5. Radnai $\mathrm{M}$ et al. A possible association between preterm birth and early periodontitis. A pilot study. J Clin Periodontol 2004; 31: 736-741.

6. Beckett H et al. Journal clubs. Br Dent J 2004; 198: 154

doi: $10.1038 /$ sj.bdj.4812920

\section{Death row dentistry}

Sir, I am writing in response to a letter about the new fees structure (BDJ 2005; 199: 249).

From an altruistic standpoint I am personally inclined to stay within the NHS, however, and I may be being a little too cynical here, I cannot help but see the whole PDS/new contract and the revised fees structure as a very well crafted method of removing dentistry from the NHS.
The PDS/new contract will have the dentist considering the treatment they provide from a 'how much will it cost me to treat this patient?' point of view, as the salary that they receive is predetermined and the laboratory bills will actually reduce their take home pay. I know that in theory we will have been paid for all of the work that we are anticipated to carry out within the salary, but human nature is inevitably going to lead to the pushing of private work to supplement that basic salary. Essentially why do an NHS crown and reduce your income when you can provide a private one and raise it?

Similarly the banding options for patient charges will almost certainly result in the provision of more private work. In dealing with a basic example, an examination and scaling costs $£ 15$ but when you add a single amalgam, no matter what the size, the price is boosted to $£ 41$.

What then, is the response of your patient going to be when offered the provision of a private composite for only $£ 25$, for example? Not only is the overall cost going to be lower for the patient but they will have a nice tooth coloured filling as well! As for the dentist, they have gained $£ 25$ but have also been paid in anticipation for the NHS amalgam. This means that we can make more money short term and gain patient approval for our actions as they too will benefit, but the NHS will lose money as a result.

The long term effect of this will be that dental salaries will be renegotiated downward as productivity levels will have fallen, and then it will be necessary to maintain that private income to retain the current level of your salary. In short, unless we place ourselves on a self imposed treadmill maintaining our GDS productivity levels, then NHS dentistry has just been given a death sentence by the government.

The government has effectively shot NHS dentistry and managed to pass us the smoking gun, as it will be us who receive the bad publicity for electing to move over to private practice, while they have merely engineered a situation where the conditions are perfect for us to do so. How much money will they be able to claw from the dental budget as a result of this to plug a hole elsewhere in their spending? So much for a caring government; it makes a mockery of the promise to provide affordable dentistry for all.

T. Clayton

By email

doi: 10.1038/sj.bdj.4812921 